\title{
BMJ Open Risk of COVID-19-related bullying, harassment and stigma among healthcare workers: an analytical cross- sectional global study
}

\author{
Timothy D Dye (D) , Lisette Alcantara, Shazia Siddiqi, Monica Barbosu, \\ Saloni Sharma, Tiffany Panko, Eva Pressman
}

To cite: Dye TD, Alcantara L, Siddiqi S, et al. Risk of COVID-19-related bullying, harassment and stigma among healthcare workers: an analytical cross-sectional global study. BMJ Open 2020;10:e046620. doi:10.1136/ bmjopen-2020-046620

- Prepublication history and additional material for this paper is available online. To view these files, please visit the journal online (http://dx.doi.org/10. 1136/bmjopen-2020-046620)

Received 04 November 2020 Revised 14 December 2020 Accepted 16 December 2020

Check for updates

(c) Author(s) (or their employer(s)) 2020. Re-use permitted under CC BY-NC. No commercial re-use. See rights and permissions. Published by BMJ.

Department of Obstetrics and Gynecology, University of Rochester, School of Medicine and Dentistry, Rochester, New York, USA

Correspondence to Professor Timothy D Dye; tim_dye@urmc.rochester.edu

\section{ABSTRACT}

Objectives Essential healthcare workers (HCW) uniquely serve as both COVID-19 healers and, potentially, as carriers of SARS-CoV-2. We assessed COVID-19-related stigma and bullying against HCW controlling for social, psychological, medical and community variables.

Design We nested an analytical cross-sectional study of COVID-19-related stigma and bullying among HCW within a larger mixed-methods effort assessing COVID-19-related lived experience and impact. Adjusted $\mathrm{OR}(\mathrm{aOR})$ and $95 \%$ Cls evaluated the association between working in healthcare settings and experience of COVID-19-related bullying and stigma, controlling for confounders. Thematic qualitative analysis provided insight into lived experience of COVID-19-related bullying.

Setting We recruited potential participants in four languages (English, Spanish, French, Italian) through Amazon Mechanical Turk's online workforce and Facebook. Participants Our sample included 7411 people from 173 countries who were aged 18 years or over.

Findings HCW significantly experienced more COVID19-related bullying after controlling for the confounding effects of job-related, personal, geographic and sociocultural variables (aOR: $1.5 ; 95 \% \mathrm{Cl} 1.2$ to 2.0 ). $\mathrm{HCW}$ more frequently believed that people gossip about others with COVID-19 (OR: $2.2 ; 95 \% \mathrm{Cl} 1.9$ to 2.6 ) and that people with COVID-19 lose respect in the community (OR: 2.3; $95 \% \mathrm{Cl} 2.0$ to 2.7), both which elevate bullying risk (OR: $2.7 ; 95 \% \mathrm{Cl} 2.3$ to 3.2 , and $\mathrm{OR}: 3.5 ; 95 \% \mathrm{Cl} 2.9$ to 4.2 , respectively). The lived experience of COVID-19-related bullying relates frequently to public identities as HCW traverse through the community, intersecting with other domains (eg, police, racism, violence).

Interpretation After controlling for a range of confounding factors, HCW are significantly more likely to experience COVID-19-related stigma and bullying, often in the intersectional context of racism, violence and police involvement in community settings.

\section{INTRODUCTION}

Stigma refers to a set of social processes invoked to label, separate and discriminate against others in a way that interferes with that individual's (or group's) life chances and opportunities. ${ }^{12}$ Stigma in the context
Strengths and limitations of this study

- A large, mixed-methods global assessment of COVID-19-related stigma and bullying with 7411 research participants from 173 countries.

- Research participants accessed the study through a recruitment link distributed through Amazon Mechanical Turk and Facebook, Instagram and the Facebook Audience Network

- Study was conducted in the four predominant languages (Spanish, Italian, French and English), where COVID-19 was most prevalent at the time of data collection.

- People without access to the internet or to these tools were unable to participate in this study.

- COVID-19-related stigma and bullying was assessed with three questions developed and tested for this study to categorise perception and experience, but we did not use more lengthy, multi-item scales that may provide nuanced information about bullying and stigma.

of healthcare represents a major barrier to sustain access to care while assuring equity and quality of services. Individual or collective beliefs and behaviours around a specific diagnosis resulting in any type of social discrimination and moral discredit prevent people from seeking care in a timely manner or even at all. Consequently, stigma has a negative impact on health outcomes aggravated by the mental health implications and social isolation that challenge public health initiatives targeting solutions for health concerns. ${ }^{34}$

Worldwide, healthcare workers also suffer the negative actions that are the result of stigmatisation, such as harassment and violent attacks inside and outside of their workplace compounded by the long working hours, psychological distress, fatigue and occupational burnout that often is intrinsic to their jobs. Stigma and harassment resulting in bullying and violence against healthcare workers could 
constitute a human rights violation, ${ }^{5}$ with clear impacts on the workers themselves, their social and work environments and patients. ${ }^{6}$ Many incidents of violence, harassment or stigmatisation have been reported against healthcare workers, patients and medical infrastructure in relation to the COVID-19 pandemic; of these recorded incidents of violence and harassment, $67 \%$ of those events were directed at healthcare workers. ${ }^{7}$ Some of these incidents include verbal and physical assault, such as patients who have deliberately coughed or spat on healthcare workers. These acts of violence have been shown to increase the levels of stress and, consequently, to exacerbate psychological sequelae resulting from moral injuries. People who have suffered discrimination and stigma are at elevated risk for mental illness, including anxiety, depression, post-traumatic stress disorder (PTSD) and suicidality. ${ }^{8}$

The global health emergency as a result of the COVID-19 pandemic has triggered a social crisis marked by discriminatory behaviours and stigma against people perceived as suspect, diagnosed or have survived the virus. Ironically, despite their role in caring for people with COVID-19, healthcare workers are no exception to experiencing stigma. ${ }^{9}$ During outbreaks of infectious diseases, frontline personnel are often stigmatised by people in their communities due to fear that they are sources of infection. ${ }^{10}$ Studies report that while often risking their own lives in exposing themselves to infection while delivering care, healthcare workers also experience stigma such as the denial of services, housing, verbal abuse or gossip and social devaluation. Moreover, their family members face 'secondary' or 'associative' stigma. ${ }^{11}$

During the COVID-19 pandemic, fear, panic, misinformation about how SARS-CoV-2 (the virus that causes COVID-19) can spread and misplaced anger are been described as some of the reasons people attack and abuse healthcare personnel. ${ }^{12}$ In the same context, in Mexico the rapid increase of COVID-19 cases have led to a series of violent incidents against healthcare workers accused of spreading the virus. Reports describe healthcare workers being threatened, beaten, sprayed with bleach and even evicted from their homes. ${ }^{13}$

While it is clear that healthcare workers experience bullying and stigma relating to COVID-19 around the world, little is known about how this risk in healthcare workers differs from others in the community, especially controlling for other factors that may also be potentially stigmatising or lead to bullying incidents. We sought to examine bullying against healthcare workers quantitatively to better identify the interaction of healthcare workers and bullying in the context of other factors, but also qualitatively to help examine the lived experience of bullying among healthcare workers around the world.

\section{MATERIALS AND METHODS}

\section{Study design}

We nested an analytical cross-sectional study within a larger mixed-methods effort assessing COVID-19-related lived experience and impact around the world. ${ }^{14}$ To evaluate the associations of interest, we a priori included assessment of lived experience relating to COVID-19related bullying, harassment, hurt and stigma, and also included assessment of whether or not the respondent or someone in their household worked in a healthcare setting. The cross-sectional design suited our needs for rapid deployment and large-scale distribution around the world, reaching potential research participants through several social media platforms.

The parent study was guided by the Critical Medical Ecological model, ${ }^{15}$ accounting for the sociocultural, biological, healthcare, abiotic data and power dynamics across the domains of individuals, households and communities in six world regions (Africa, Asia, Europe, Latin America and the Caribbean, Northern America and Oceania).

We used the Strengthening the Reporting of Observational Studies in Epidemiology cross-sectional checklist when writing this report ${ }^{16}$ along with the Consolidated Criteria for Reporting Qualitative Research ${ }^{17}$ guidelines.

\section{Setting}

We implemented this study online and globally through the University of Rochester's installation of REDCap (V.9.9.2, Vanderbilt University) in English, Spanish, French and Italian, which reflected the primary languages found in the parts of the world where the most COVID-19 cases were emerging during the period of this study (6 April 2020 to 29 May 2020). ${ }^{18}$ Data collection was stopped once we reached our sample size goals.

\section{Sample size}

The a priori sample size for the parent study recruited participants from six geographic regions ${ }^{19}$ (Africa, Asia, Europe, Northern America, Latin America and the Caribbean and Oceania) based on the International Standard Organization 3166 Country Codes ${ }^{20}$ of participant residence. This estimation yielded 380 participants required per region, which we inflated by $50 \%$ (to 570 ), to account for multivariate analysis, missing data and subanalyses. For this particular nested analysis, we conducted a post hoc power computation and estimated that with a $99 \%$ two-sided CI that our sample size exceeded $80 \%$ power to detect an effect size of at least 1.5 with normal approximation and continuity correction (JMP Pro V.15.0.0 (SAS Institute, Cary, North Carolina, USA)).

\section{Respondents}

Participants were recruited through two social media platforms: (1) the Amazon Mechanical Turk ('mTURK') online workforce ${ }^{21}$ and (2) through Facebook, Instagram and the Facebook Audience Network. ${ }^{22}$ Facebook's platforms are widely accessible globally and frequently are used survey research. ${ }^{22}$ mTURK enables access to a multilingual digital workforce, providing the ability to recruit global research participants, including those without Facebook platform access. ${ }^{21}$ Inclusion criteria included 
self-identification as age 18 years and older and able to complete the survey in English, Spanish, French or Italian. Participants recruited through mTURK and Facebook were routed to the REDCap survey in the language of recruitment (English, Spanish, French, Italian), were presented with the Research Subjects Review Board (RSRB)-approved Information Sheet in that language, provided consent to continue and were asked to confirm their age and country of residence. To accommodate their role as a digital workforce to reach harder-to-access populations, mTURK respondents were paid between US $\$ 1.00$ and US\$3.00 for participation. ${ }^{23}{ }^{24}$ Facebook or Instagram respondents were not compensated. Additional recruitment details are available elsewhere. ${ }^{25}$ In total, 7411 individuals (40\% recruited through mTURK, and 60\% recruited from Facebook) represented 173 countries that were included in the final sample.

\section{Measures}

This nested study included question formats around COVID-19-specific actions, perceptions and experiences mostly derived from the Kaiser Family Foundation (KFF)'s Coronavirus Poll, ${ }^{26}$ or that were constructed and tested by the project team for flow and understandability (see supplemental material for instruments in English (see online supplemental file 1), Spanish (see online supplemental file 2), French (see online supplemental file 3) and Italian (see online supplemental file 4)). Personal experience with COVID-19 included testing, perception of infection, adherence to prevention strategies and recommendations (masking, social-physical distancing, working from home) and COVID-19-related morbidity or mortality in friends, family or neighbours. Sociodemographic measures included age, gender, education, ownership of material assets (car and home), country of residence (mapped to region) and social media use. Household-related responsibilities included care for elderly and care for children, and health variables included the presence of a chronic health condition in the participant or in a household member.

The primary exposure of interest was whether or not the participant worked in a healthcare setting, the focus of this analysis. We assessed this by asking the KFF Coronavirus Poll ${ }^{26}$ question: Do you or anyone in your household work in a healthcare delivery setting, such as a doctor's office, clinic, hospital, nursing home or dentist's office?

\section{Outcome: COVID-19-related harassment, bullying and stigma}

The primary outcome for this nested analysis was COVID19-related harassment and bullying. To assess this phenomenon, we created and tested the following question: Have you or a family member been harassed, bullied or hurt because of coronavirus? Response options to this question were 'yes', 'no' and 'do not know'. To identify specifically those who had perceived they or a family member were harassed, bullied or hurt, we consolidated 'no' and 'do not know' into one category, and 'yes' into another. If the participant indicated that they or a family member had been harassed, bullied or hurt because of coronavirus they were subsequently asked to explain their response (open-ended).

Of secondary interest in our analysis is the ascertainment of participant perception of coronavirus stigma. We adapted two stigma questions from STRIVE ${ }^{27}$ for this purpose: Do people talk badly or gossip about other people who are living with, have had or are thought to have coronavirus infection (or COVID-19)? and Do people who have had coronavirus infection (or COVID19) lose respect or status in the community? Participant responses to both questions were 'definitely yes', 'probably yes', 'probably not', 'definitely not' and 'do not know'. In analysis, these questions were reduced to two categories: 'definitely' or 'probably yes' in one category, and the other options in another.

\section{Statistical analysis}

All variables included in this study were cross-tabulated with the predictor variable of interest (healthcare worker) and the primary outcome (COVID-19-related harassment or bullying). Numbers and percentages are used to display distribution and Pearson's $\chi^{2}$ analyses and their associated $p$ values are used to compute and display significance.

Logistic regression was used to compute ORs for COVID-19-related harassment or bullying by healthcare worker status, with the OR point estimate and 95\% CI conveying magnitude and certainty of the association. Following the approach by Hosmer and Lemeshow, ${ }^{28}$ variables marginally (or more) associated with both the predictor and outcome variables $(\mathrm{p}<0.10)$ were included in a multivariate logistic regression to assess potential confounding. Additionally, to address collinearity, only variables with a Variance Inflation Factor value $<0.05$ were retained in the model. Variables not displaying linearity with the predictor and outcome variables were excluded from the multivariate analysis. The Hosmer and Lemeshow goodness-of-fit statistic was used to assess the degree to which the data fit the final model. We used a forward stepwise conditional approach for assessing and including variables in the multivariate model, aiming to achieve a parsimonious, explanatory model. IBM SPSS Statistics (V.25) was used for analysis. The significance level of all tests was set at $5 \%$. Records missing data were excluded from bivariate and multivariate analyses.

\section{Qualitative coding and analysis}

In total, 327 participant-level open-ended responses explaining COVID-19-related harassment and bullying situations and perspectives were coded by a team of coders. Responses were translated into English and coding was conducted in English. A review of qualitative responses generated an 11-item codebook. Coders applied codes to all qualitative responses, discussing and resolving differences in code application. Descriptive analysis of qualitative codes is presented to denote magnitude of response to identify themes, and direct quotations 
from healthcare workers are presented to illustrate examples of those themes. Participant quotes are edited only occasionally when there are clear spelling, punctuation or usage errors that impede understanding. Any potentially identifying or stigmatising details, including country, are deleted or masked.

\section{Ethical review}

All participants provided informed consent to engage in this research after a review of a detailed Information Sheet presented in English, French, Spanish or Italian at the beginning of the REDCap survey. Participants could skip any question in the survey except age and country of residence. All staff associated with this study completed CITIProgram's Research, Ethics and Compliance Training.

\section{Public involvement}

The instrument for this study was pretested and subsequently edited with a non-random selection of public participants. Public comments were allowed on social media recruitment materials and advertisements about the topic, the study and participation. Publications that result from this study will be disseminated back to the public via social media channels. Finally, we included an evaluation of the survey experience at the end of the REDCap encounter, which allowed participants to communicate their thoughts and experiences about answering the questions and participating in this work. Public input on the survey and experience were considered in shaping the results and interpretations from this project.

\section{RESULTS}

In total, 595 participants in this study $(8.0 \%$ of the total sample size) indicated they or a family member experienced COVID-19-related harassment, bullying or hurt, and 837 participants (11.3\% of the total sample size) indicated they worked in a healthcare delivery setting, such as a doctor's office, clinic, hospital, nursing home or dentist's office.

Overall, shown in table 1, people who worked in healthcare settings were significantly more likely to believe they have-or have had-coronavirus infection, or COVID-19 (OR: 2.7; 95\% CI 2.2 to 3.3) than their counterparts who did not work in a healthcare setting. In fact, people who work in healthcare settings are also significantly more likely than others to have actually tested positive for COVID-19 (OR: 2.2; 95\% CI 1.4 to 3.4). Participants receiving positive COVID-19 test results were significantly more likely to experience COVID-19-related bullying (OR: 4.8 ; 95\% CI 3.0 to 7.7), as were participants generally who believed they had had COVID-19 previously (OR: $5.4 ; 95 \%$ CI 4.4 to 6.6 ).

Healthcare workers were less likely to follow socialphysical distancing compared with participants who were not healthcare workers (OR: 0.7 ; $95 \%$ CI 0.6 to 0.9 ), and were less likely to be able to do their jobs from home (OR:
$0.4 ; 95 \%$ CI 0.4 to 0.5$)$. Both of these factors were related similarly to COVID-19-related bullying: people less likely to follow social-physical distancing closely (OR: 1.8; 95\% CI 1.4 to 2.3 ) and those who could not do their jobs from home (OR: $1.3 ; 95 \%$ CI 1.1 to 1.5 ) were more likely to experience bullying than were other participants.

While there were no significant differences between age and gender distribution between healthcare workers and other workers, healthcare workers were more likely to have education beyond high school (OR: 1.9; 95\% CI 1.4 to 2.4). Education level (years of education completed) was not associated with COVID-19-related harassment and bullying in either healthcare workers or non-healthcare workers $(\mathrm{p}=0.103, \mathrm{p}=0.312$, respectively; data not shown). Age was not related to experiencing COVID-19-related harassment or bullying. Participants identifying as a gender other than male or female were more likely to experience COVID-19 bullying (OR: 5.7; $95 \%$ CI 2.9 to 11.6$)$.

Healthcare workers were more likely to procure and wear a mask than non-health care workers (OR: 1.3; 95\% CI 1.1 to 1.5); mask-wearers were protected, however, from COVID-19-related harassment and bullying (OR: 0.7; $95 \%$ CI 0.6 to 0.8 ). Healthcare workers were significantly more likely to know a family member, friend or neighbour who has had COVID-19 (OR: 2.8; 95\% CI 2.4 to 3.2) and to know someone who has died from COVID-19 (OR: 4.0; $95 \%$ CI 3.4 to 4.8 ). Having a family member, friend or neighbour die from COVID-19 was also a risk factor for COVID-19-related harassment and bullying (OR: 4.1; 95\% CI 3.3 to 5.0 ), as was knowing someone who had had COVID-19 (OR: 2.5; 95\% CI 2.1 to 3.0).

Healthcare workers were more likely to use social media daily than other workers (OR: $1.3 ; 95 \%$ CI 1.1 to 1.5). However, people who used social media daily were significantly less likely to experience COVID-19-related bullying (OR: $0.6 ; 95 \%$ CI 0.5 to 0.7 ).

Asia (16.0\%), Africa $(13.6 \%)$, Northern America $(12.1 \%)$ and Latin America and the Caribbean (11.4\%) had the highest proportions of healthcare workers that participated in our study, while Europe $(6.2 \%)$ and Oceania $(6.9 \%)$ had the lowest. East Africa (16.7\%), South Asia $(17.0 \%)$ and the Caribbean $(14.7 \%)$ were subregions with the highest proportion of healthcare workers. Participants in Africa, Asia, Northern America and Oceania as a cluster of higher-prevalence regions were significantly more likely to experience COVID-19related bullying than were Latin America and Europe as a cluster of lower-prevalence regions (OR: 1.9; 95\% CI 1.6 to 2.3). Sub-Saharan Africa (14.0\%), Southern Asia $(10.7 \%)$ and Northern America $(10.6 \%)$ had the highest rates of participant experiences of COVID-19-related bullying.

Healthcare workers were significantly more likely to have a chronic illness than were non-health care workers (OR: 2.0; 95\% CI 1.7 to 2.4), and also are more likely to have someone in their household with a chronic disease (OR: $1.5 ; 95 \%$ CI 1.3 to 1.8 ). Those with chronic illnesses 
Table 1 Association of demographic, residential, household and COVID-19-related variables with working in healthcare setting and COVID-19-related harassment and bullying

$\begin{aligned} & \text { Do you work in a healthcare delivery setting, Have you or a family member been } \\ & \text { such as a doctor's office, clinic, hospital, } \\ & \text { nursing home or dentist's office? }\end{aligned}$
$\begin{array}{ll}\text { harassed, bullied or hurt because of } \\ \text { coronavirus? }\end{array}$

\begin{tabular}{ll}
$\begin{array}{l}\text { Yes (checked), } \\
\text { I do work in } \\
\text { a healthcare } \\
\text { setting }\end{array}$ & $\begin{array}{l}\text { No (not checked), } \\
\text { I do not work in a } \\
\text { healthcare setting }\end{array}$ \\
\cline { 2 - 2 }$(\mathrm{n}=837)$ & $(\mathrm{n}=6574)$
\end{tabular}
coronavirus?

$\begin{array}{ll}\text { Yes, I or } & \begin{array}{l}\text { No, I or } \\ \text { someone } \\ \text { have/has } \\ \text { someone have } \\ \text { not/has not } \\ \text { been bullied }\end{array}\end{array}$

Among those tested: what was the result of the test for coronavirus?

\begin{tabular}{|c|c|c|c|c|c|c|}
\hline Tested COVID-19 positive & $62(52.5)$ & $56(47.5)$ & $<0.001$ & $61(51.7)$ & $57(48.3)$ & $<0.001$ \\
\hline Tested COVID-19 negative & $99(33.2)$ & $199(66.8)$ & & $54(18.1)$ & $244(81.9)$ & \\
\hline \multicolumn{7}{|c|}{ o you feel you now have-or have you recently had-coronavirus infection? } \\
\hline Believe have/have had COVID-19 & $151(24.6)$ & $463(75.4)$ & $<0.001$ & $167(27.2)$ & $446(72.8)$ & $<0.001$ \\
\hline Do not believe have/have had COVID-19/ & $678(10.8)$ & $5597(89.2)$ & & $406(6.5)$ & 5856 (93.5) & \\
\hline
\end{tabular}

DK if had COVID-19

How closely are you following social or physical distancing, that is, staying at home, away from other people whenever you can or staying away from other people when in a public place?

\begin{tabular}{|c|c|c|c|c|c|c|}
\hline Followed social distancing closely & $716(11.7)$ & $5428(88.3)$ & 0.003 & $475(7.7)$ & $5655(92.3)$ & $<0.001$ \\
\hline Not followed social distancing closely & $118(15.4)$ & $647(84.6)$ & & $101(13.3)$ & $660(86.7)$ & \\
\hline \multicolumn{7}{|c|}{ Bought or worn a protective mask (since the coronavirus outbreak) } \\
\hline Did not buy or wear mask & $146(9.8)$ & $1350(90.2)$ & 0.011 & $164(11.1)$ & $1309(88.9)$ & $<0.001$ \\
\hline Bought or wore mask & $682(12.1)$ & $4943(87.9)$ & & $428(7.7)$ & $5108(92.3)$ & \\
\hline \multicolumn{7}{|c|}{ Do you personally know someone who has died from coronavirus infection (or COVID-19)? } \\
\hline $\begin{array}{l}\text { Did not have family, friend or neighbour } \\
\text { die from COVID-19 }\end{array}$ & $626(9.4)$ & $6068(90.6)$ & $<0.001$ & $431(6.8)$ & $5905(93.2)$ & $<0.001$ \\
\hline $\begin{array}{l}\text { Had family, friend or neighbour die from } \\
\text { COVID-19 }\end{array}$ & $211(29.4)$ & $506(70.6)$ & & $164(22.9)$ & $551(77.1)$ & \\
\hline
\end{tabular}

Do you personally know someone who has coronavirus infection (or COVID-19)?

\begin{tabular}{|c|c|c|c|c|c|c|}
\hline $\begin{array}{l}\text { Do not have family, friend or neighbour } \\
\text { with COVID-19 }\end{array}$ & $505(8.7)$ & 5315 (91.3) & $<0.001$ & $356(6.5)$ & 5106 (93.5) & $<0.001$ \\
\hline Have family, friend or neighbour with & $332(20.9)$ & $1259(79.1)$ & & $239(15.0)$ & $1350(85.0)$ & \\
\hline
\end{tabular}
COVID-19

If you were required to remain at home because of quarantine or school or work closure, would you be able to do at least part of your job from home, or not?

$\begin{array}{llllll}\text { Could work from home/DK/NA } & 516(9.9) & 4678(90.1) & <0.001367(7.1) & 4815(92.9) & <0.001 \\ \text { Could not work from home } & 302(21.0) & 1138(79.0) & 179(12.4) & 1259(87.6) & \end{array}$

What best describes your education?

\begin{tabular}{|c|c|c|c|c|c|c|}
\hline High school or less education & $69(7.2)$ & $884(92.8)$ & $<0.001$ & $77(8.1)$ & $873(91.9)$ & 0.729 \\
\hline More than high school education & $638(12.8)$ & $4362(87.2)$ & & $387(7.8)$ & 4590 (92.2) & \\
\hline \multicolumn{7}{|l|}{ What is your current age, in years? } \\
\hline Age under 32 years & $247(12.2)$ & $1770(87.8)$ & 0.7 & $165(8.2)$ & $1842(91.8)$ & 0.721 \\
\hline Age 32 years or more & $493(11.9)$ & $3648(88.1)$ & & $328(8.0)$ & $3794(92.0)$ & \\
\hline \multicolumn{7}{|c|}{ Which of the following best describes your gender: } \\
\hline Male & $366(11.3)$ & $2861(88.7)$ & 0.161 & $294(9.2)$ & $2918(90.8)$ & $<0.001$ \\
\hline Female & $363(12.8)$ & 2465 (87.2) & & $188(6.7)$ & $2629(93.3)$ & \\
\hline Other option & $3(8.3)$ & $33(91.7)$ & & $12(33.3)$ & $24(66.7)$ & \\
\hline \multicolumn{7}{|l|}{ Use social media daily } \\
\hline Does not use social media daily & $156(9.5)$ & $1494(90.5)$ & 0.007 & $158(12.1)$ & $1146(87.9)$ & $<0.001$ \\
\hline Uses social media daily & $681(11.8)$ & $5080(88.2)$ & & 437 (7.6) & $5310(92.4)$ & \\
\hline
\end{tabular}


Table 1 Continued

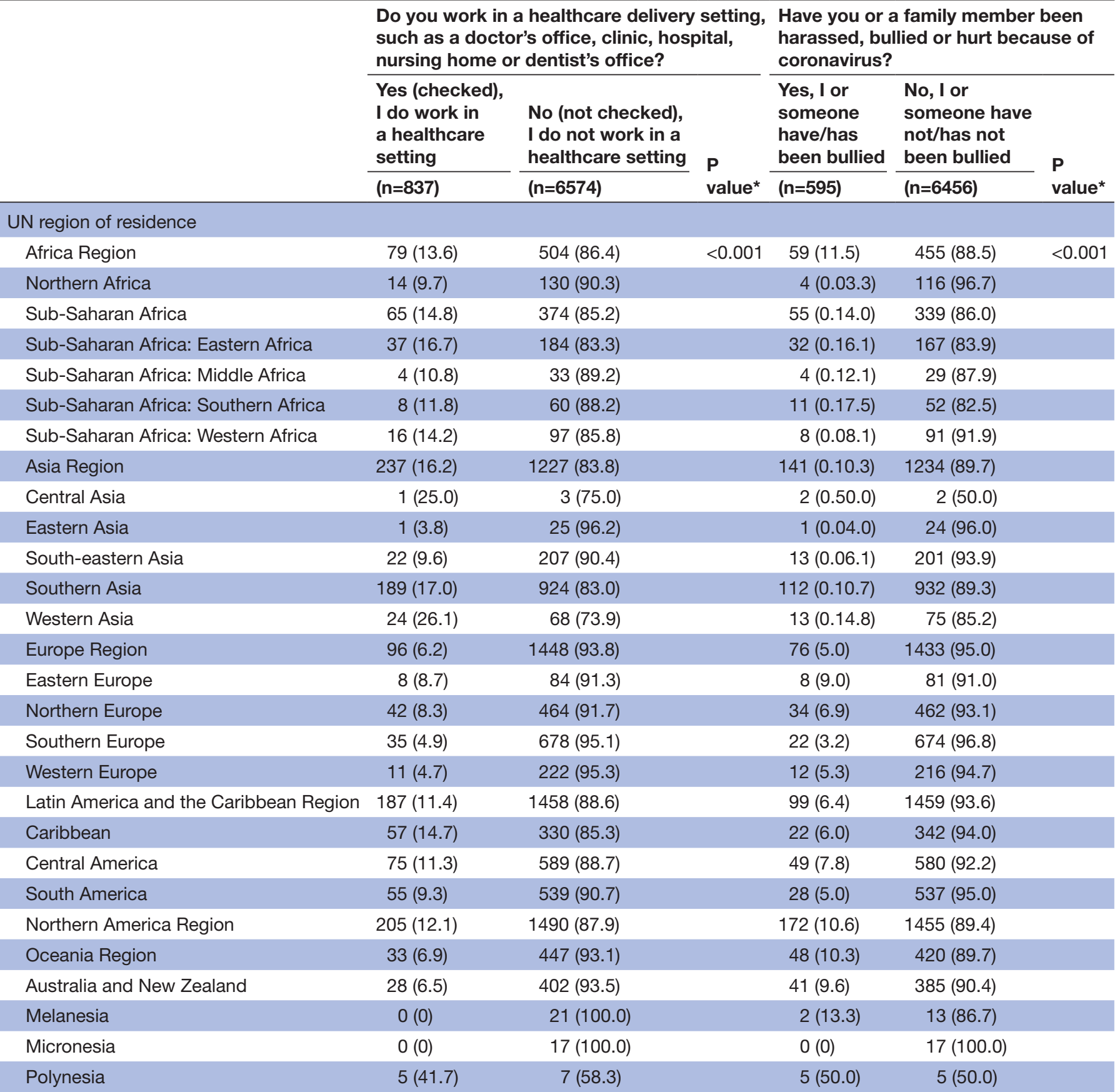

Do you or does someone in your household have a serious health condition such as high blood pressure, heart disease, lung disease, cancer or diabetes?

\begin{tabular}{|c|c|c|c|c|c|c|}
\hline I do not have a chronic disease & $569(9.6)$ & $5335(90.4)$ & $<0.001$ & $402(7.2)$ & $5146(92.8)$ & $<0.001$ \\
\hline I have a chronic disease & $268(17.8)$ & 1239 (82.2) & & $193(12.8)$ & $1310(87.2)$ & \\
\hline $\begin{array}{l}\text { No one in my household has a chronic } \\
\text { disease }\end{array}$ & $553(10.1)$ & 4927 (89.9) & $<0.001$ & $421(8.2)$ & $4703(91.8)$ & 0.274 \\
\hline $\begin{array}{l}\text { Someone else in my household has a } \\
\text { chronic disease }\end{array}$ & $284(14.7)$ & $1647(85.3)$ & & $174(9.0)$ & $1753(91.0)$ & \\
\hline \multicolumn{7}{|l|}{$\begin{array}{l}\text { Are you responsible for taking care of } \\
\text { children? }\end{array}$} \\
\hline I am not responsible for care of children & $388(9.7)$ & $3622(90.3)$ & $<0.001$ & $254(6.3)$ & $3748(93.7)$ & $<0.001$ \\
\hline I am responsible for care of children & $432(16.4)$ & 2205 (83.6) & & $295(11.2)$ & $2334(88.8)$ & \\
\hline
\end{tabular}

Continued 


\begin{tabular}{|c|c|c|c|c|c|}
\hline \multicolumn{3}{|c|}{$\begin{array}{l}\text { Do you work in a healthcare delivery setting, } \\
\text { such as a doctor's office, clinic, hospital, } \\
\text { nursing home or dentist's office? }\end{array}$} & \multicolumn{3}{|c|}{$\begin{array}{l}\text { Have you or a family member been } \\
\text { harassed, bullied or hurt because of } \\
\text { coronavirus? }\end{array}$} \\
\hline $\begin{array}{l}\text { Yes (checked), } \\
\text { I do work in } \\
\text { a healthcare } \\
\text { setting }\end{array}$ & $\begin{array}{l}\text { No (not checked), } \\
\text { I do not work in a } \\
\text { healthcare setting }\end{array}$ & \multirow{2}{*}{$\begin{array}{l}\mathbf{P} \\
\text { value*}^{*}\end{array}$} & $\begin{array}{l}\text { Yes, I or } \\
\text { someone } \\
\text { have/has } \\
\text { been bullied }\end{array}$ & $\begin{array}{l}\text { No, I or } \\
\text { someone have } \\
\text { not/has not } \\
\text { been bullied }\end{array}$ & \multirow{2}{*}{$\begin{array}{l}P \\
\text { value }^{*}\end{array}$} \\
\hline$(n=837)$ & $(n=6574)$ & & $(n=595)$ & $(n=6456)$ & \\
\hline
\end{tabular}

Are you responsible for taking care of any elderly people?

\begin{tabular}{|c|c|c|c|c|c|c|}
\hline I am not responsible for care of elders & $378(8.6)$ & $4039(91.4)$ & $<0.001$ & $254(6.3)$ & $3748(93.7)$ & $<0.001$ \\
\hline I am responsible for care of elders & $450(19.5)$ & $1855(80.5)$ & & $289(12.6)$ & $2009(87.4)$ & \\
\hline
\end{tabular}

Do anyone in your household work in a healthcare delivery setting, such as a doctor's office, clinic, hospital, nursing home or dentist's office?

No one else in my household works in a $754(11.5) \quad 5806(88.5) \quad 0.131 \quad 474(7.6) \quad 5730(92.4) \quad<0.001$
healthcare setting

Someone else in my household works in $83(9.8) \quad 768(90.2) \quad 121(14.3)$
a healthcare setting

Do you own a car?

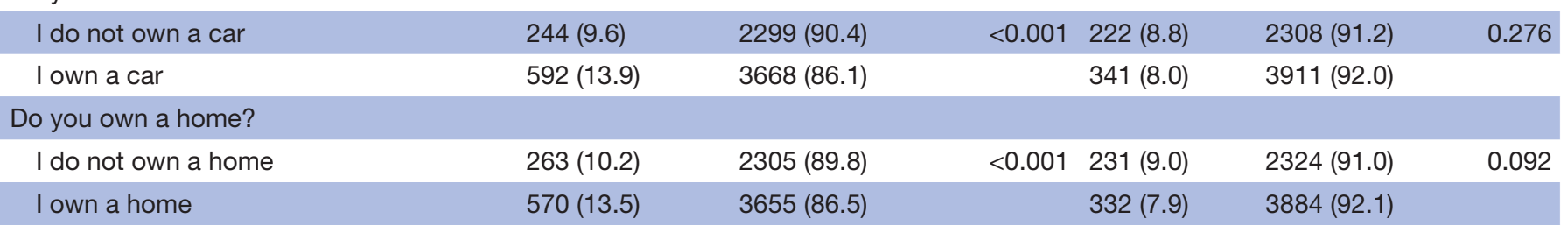

Do people who have had coronavirus infection (or COVID-19) lose respect or status in the community?

\begin{tabular}{|c|c|c|c|c|c|c|}
\hline $\begin{array}{l}\text { People with COVID-19 lose status in the } \\
\text { community }\end{array}$ & 306 (20.2) & $1208(79.8)$ & & $264(17.5)$ & 1241 (82.5) & $<0.001$ \\
\hline $\begin{array}{l}\text { People with COVID-19 do not lose status } \\
\text { in the community }\end{array}$ & $530(9.8)$ & 4865 (90.2) & & $309(5.7)$ & 5079 (94.3) & \\
\hline \multicolumn{7}{|c|}{$\begin{array}{l}\text { Do people talk badly or gossip about other people who are living with, have had or are thought to have coronavirus infection (or } \\
\text { COVID-19)? }\end{array}$} \\
\hline $\begin{array}{l}\text { People gossip about other people with } \\
\text { COVID-19 }\end{array}$ & $353(18.8)$ & 1525 (81.2) & $<0.001$ & $274(14.6)$ & 1598 (85.4) & $<0.001$ \\
\hline $\begin{array}{l}\text { People do not gossip about other people } \\
\text { with COVID-19 }\end{array}$ & $476(9.5)$ & $4532(90.5)$ & & 297 (5.9) & 4702 (94.1) & \\
\hline
\end{tabular}

${ }^{*} \mathrm{P}$ value $\left(\chi^{2}\right)$.

DK, Don't Know; NA, not available.

themselves (OR: $1.9 ; 95 \%$ CI 1.6 to 2.3 ) were more likely to experience COVID-19-related bullying.

Healthcare workers were more likely to have child care responsibilities (OR: 1.8; 95\% CI 1.6 to 2.1 ) and elder care responsibilities (OR: 2.6; 95\% CI 2.2 to 3.0) than were non-healthcare workers. Both groups-those with child care responsibilities and those with elder care responsibilities-were at greater risk for COVID-19-related bullying (OR: $1.9 ; 95 \%$ CI 1.6 to 2.2 and OR: $2.2 ; 95 \%$ CI 1.9 to 2.7 , respectively).

Healthcare workers were more likely to have access to material assets, being more likely to own both a car (OR: 1.5; 95\% CI 1.3 to 1.8 ) and a home (OR: $1.4 ; 95 \%$ CI 1.2 to 1.6$)$ than were non-healthcare workers. Neither car ownership nor home ownership, however, was related to COVID-19-related bullying.

\section{Stigma}

Overall, $27.3 \%$ of participants believed that people talk badly or gossip about other people who are living with, have had or are thought to have COVID-19, and $21.9 \%$ of participants believed people who have had COVID-19 lose respect or status in the community. Perceptions of COVID-19 stigma varied considerably around the world: participants from Asia (39.2\%), Africa (37.8\%) and Latin America and the Caribbean $(33.6 \%)$ were more likely to believe that people talk badly or gossip about other people who are living with, have had or are thought to have COVID-19 than did participants in Europe (21.7\%), Northern America (16.5\%) and Oceania (16.0\%). Similarly, participants from Asia (34.1\%), Africa (29.6\%) and Latin America and the Caribbean (29.0\%) were more likely to note that people who have had COVID-19 lose 
Table 2 Bivariate and multivariate analysis of work in healthcare settings and COVID-19-related harassment and bullying

7e. Have you or a family member been harassed, bullied or hurt because of coronavirus?

\begin{tabular}{|c|c|c|c|c|c|c|}
\hline $\begin{array}{l}\text { Yes, I or } \\
\text { someone } \\
\text { have/ } \\
\text { has been } \\
\text { bullied } \\
(\mathrm{n}=595)\end{array}$ & $\begin{array}{l}\text { No, I or } \\
\text { someone } \\
\text { have not/ } \\
\text { has not been } \\
\text { bullied } \\
(\mathrm{n}=6456)\end{array}$ & $\begin{array}{l}\text { Total } \\
(n=7051)\end{array}$ & $X^{2}$ test & $\begin{array}{l}P \\
\text { value }\end{array}$ & $\begin{array}{l}\text { Model 1: } \\
\text { unadjusted } \\
\text { OR }(95 \% \mathrm{CI})\end{array}$ & $\begin{array}{l}\text { Model 2: } \\
\text { adjusted* OR } \\
(95 \% \mathrm{Cl})\end{array}$ \\
\hline
\end{tabular}

Do you or anyone in your household work in a healthcare delivery setting, such as a doctor's office, clinic, hospital, nursing home or dentist's office?

\begin{tabular}{llllll} 
I work in a healthcare setting & $151(18.1)$ & $685(81.9)$ & 836 & $113.689<0.0012 .9(2.3$ to 3.5$)$ & $1.5(1.2$ to 1.9$)$ \\
\hline I do not work in a healthcare setting & $444(7.1)$ & $5771(92.9)$ & 6215 &
\end{tabular}

*Adjusted for: could not work from home, have/have had COVID-19, have not closely followed social-physical distancing, have friend/ family/neighbour with COVID-19, have friend/family/neighbour who died from COVID-19, have at least one chronic disease, have child care responsibilities, have elder care responsibilities, reside in Africa/Asia/Northern America/Oceania.

respect or status in the community than did participants in Europe $(11.9 \%)$, Northern America $(14.8 \%)$ and Oceania $(11.9 \%)$.

Healthcare workers were more likely to believe that people talk badly or gossip about other people who are living with, have had or are thought to have COVID-19 (OR: 2.2; 95\% CI 1.9 to 2.6 ) and that people who have had COVID-19 lose respect or status in the community (OR: 2.3; 95\% CI 2.0 to 2.7). People who hold such beliefs are more likely to have experienced COVID-19-related harassment or bullying: those believing that people with COVID-19 are talked badly or gossiped about were significantly more likely to have experienced COVID-19-related bullying (OR: 2.7; 95\% CI 2.3 to 3.2), as do people who feel others with COVID-19 lost respect or status in the community (OR: 3.5; 95\% CI 2.9 to 4.2). People who believe they have had COVID-19 infection themselves, know someone who's had COVID-19 or knows someone who's died from COVID-19 are all significantly more likely to believe people are talked badly about or gossiped or that they lose status and respect in the community (data not shown).

\section{Multivariate model}

Shown in table 2, people who work in healthcare settings are significantly more likely to experience COVID-19related harassment, bullying or hurt (OR: 2.9; 95\% CI: 2.3 to 3.5 ), even after controlling for the confounding effects of not being able to work from home, having had COVID-19 themselves, not having closely followed socialphysical distancing, having a family member, friend or neighbour with or die from COVID-19, having at least one chronic disease, having child and elder care responsibilities and residing in Africa/Asia/Northern America/ Oceania (aOR: 1.5; 95\% CI 1.2 to 2.0 ). Finally, the lack of significance in the Hosmer and Lameshow goodness-of-fit statistic indicates the data fits the model well $(p=0.990$; data not shown).

\section{Qualitative}

The code most commonly applied to qualitative excerpts describing harassing/bullying/hurtful experiences related to COVID-19 was 'happened in/related to community', noted by 109 participants (table 3). This broad code encompasses a range of types of experiences. For instance, some community-related bullying commonly applies to people who are suspected of having COVID-19, perhaps through experiencing one of COVID-19's symptoms:

One relative had fever and villagers thought it was for coronavirus. They wanted to lock the house and hand over [her] to police. Later on the matter was solved. People are being harsh to a suspected COVID-19 patient. (Participant from South Asia)

I have COPD and allergies. People would get very mean if I coughed or sniffled. That is one of the major reasons I'm home. (Male participant, in his 60s, North America)

Coughed while using public transportation. Was almost put out... (Female participant, in her 40s, from the Caribbean)

$\mathrm{Si}$ estornudas aunque tengas la mascarilla y te tapes con el antebrazo la gente te habla y te mira mal. (If you sneeze even if you have the mask and cover yourself with your forearm, people talk to you and look at you badly.) (Female participant, in her 20s, from the Caribbean)

My grandchild was outside with his father walking around the building, just to get a fresh air, no one was around. the premises have a locked fence usually. and some "good" neighbours called the police and they came, didn't get fined though, but got warning. It is so much for solidarity... (Female participant, in her 60s, Southwestern Europe) 
Table 3 Frequency of qualitative codes applied to COVID-19-related harassment/bullied/hurt excerpts

\begin{tabular}{|c|c|c|}
\hline $\begin{array}{l}\text { Qualitative code (7e. been } \\
\text { harassed, bullied or hurt } \\
\text { because of coronavirus, } \\
\text { please explain) }\end{array}$ & $\begin{array}{l}\text { Applied to } \\
\text { excerpts (\# } \\
(\%))(n=327)\end{array}$ & Example quotation \\
\hline $\begin{array}{l}\text { Happened in/related to the } \\
\text { community }\end{array}$ & $109(33.1)$ & $\begin{array}{l}\text { Mi sobrina que es Medica, la Hostigan en su domicilio los vecinos diciendolae } \\
\text { que se valla de alli... (My niece, who is a doctor, is harassed at her home by the } \\
\text { neighbors telling her to get out of there...) (Participant from South America) }\end{array}$ \\
\hline Involved violence & $44(13.4)$ & $\begin{array}{l}\text { Son [is] deputy supermarket manager-has been threatened and verbally } \\
\text { abused at work. (Participant from Western Europe, } 60 \text { s) }\end{array}$ \\
\hline Racism & $27(8.2)$ & $\begin{array}{l}\text { My partner and his family as Asian, and they have been on the receiving end } \\
\text { of racist remarks and harassment for the last } 3 \text { months because of this virus. } \\
\text { (Early } 20 \text { s, other gender, Northern Europe) }\end{array}$ \\
\hline Happened in/related to work & $21(6.4)$ & $\begin{array}{l}\text { Mi esposa trabaja en un hospital. Los vecinos no nos hablan. (My wife works } \\
\text { in a hospital. Neighbors don't speak to us.) (Male participant, in his } 30 \text { s, } \\
\text { Caribbean) }\end{array}$ \\
\hline Happened within the family & $19(5.8)$ & $\begin{array}{l}\text { We were harassed and bullied by our overseas family, they called us cowards } \\
\text { and a lot of other nasty things and tried to pressure us into continuing with } \\
\text { overseas travel plans (we had asked them not to visit us as previously planned } \\
\text { due to concerns about the virus). (Female participant, in her } 20 \text { s, from Oceania) }\end{array}$ \\
\hline Bullied for wearing mask & $15(4.6)$ & $\begin{array}{l}\text { Yelled at for wearing a mask. Coughed on at a gas station. Just hate going } \\
\text { out... (Female participant, in her } 60 \mathrm{~s} \text {, from North America) }\end{array}$ \\
\hline $\begin{array}{l}\text { Bullied for NOT wearing a } \\
\text { mask }\end{array}$ & $7(2.1)$ & $\begin{array}{l}\text { E' stato picchiato poichè non aveva la mascherina. Ma non è colpa sua se } \\
\text { non è possibile comprarle o trovarle nei negozi... (He was beaten because he } \\
\text { didn't have a mask. But it's not his fault that you can't buy them or find them in } \\
\text { stores.) (Male participant, in his } 20 \text { s, from Southern Europe) }\end{array}$ \\
\hline
\end{tabular}

Often, community-related COVID-19-related bullying/ experiences relate to an individual's perception of support (or lack thereof) regarding adherence to (or not) of prevention strategies:

Too many science illiterate people [are] criticizing and mocking scientists because they do not understand the job that we do, and would rather believe in conspiracy theories. (Male participant, in his 20s, from the Caribbean)

The [people] criticizing the government approach openly, both scientists, medical professionals, and ordinary people, have been ostracized here up until now. Many lose friends and are accused almost of 'treason' when we care about the lives of our fellow citizens. (Female participant, in her 50s, Scandanavia)

Subject to verbal abuse for leaving home. Public hysteria is such that many now labour under the misguided notion that stepping outside will lead to certain death. The media have exacerbated this and the government have done nothing to curb it. (Female participant, in her 50s, Northern Europe)

Claro al no tener miedo no sigo las recomendaciones y eso molesta a algunos (Of course, not being afraid,
I do not follow the recommendations and that annoys some.) (Male participant, in his 40s, Central America)

Aggressed by people screaming 'Stay at home' when you just do some jogging on your own, people calling the police because a child is outside playing alone in a condominium space. (Male participant, in his 70s, Southern Europe)

One environment that emerges as a common site of COVID-19-related harassment/bullying is the supermarket or other types of stores. Participants commonly note that encounters in the store environment can become contentious:

The staff at the grocery store told me that my ADA covered disability, 'does not matter' because of COVID-19. I reported them. (Female participant, in her 60s, North America)

My mother was told off for driving to the supermarket so I could put groceries in her boot. This was by a neighbor... (Female participant, in her 50s, Oceania) 
Grocery shopper thought I wasn't using proper social distancing. (Male participant, in his 50s, Northern America)

Was pushed in a Dollar General store over toilet paper... (Female participant, in her 50s, Northern America)

I have witnessed people in the grocery store totally loose it when another person got too close. (Male participant, in his 70s, Northern America)

Some animal coughed over my wife. Store security arrested him and the police took the mongrel away. My wife has had to be tested each day for a week to ensure she had not contracted the virus. Happily, she did not test positive... (Male participant, in his 60s, Oceania)

I went to a secondary supermarket in my town and was harassed by the shop guard; he felt that it was only appropriate for one person in a household to do the weekly shopping. I pay for my food, and my roommate pays for hers. Since we were at the store together, he felt that he would mess with us. (Male participant, in his 40s, Northern Europe)

Because I became a Person under Monitoring (a suspect case), neighbors were unwilling to talk to me in person. When I got to the convenience store, people would literally flee, or keep their distance. (Woman participant, in her 50s, Southeast Asia)

The second most commonly mentioned COVID-19related harassment or bullying scenario participants note involves police, authorities or government officials. As with the 'Community' sources of bullying, these sources relate to specific incidents experienced by participants but also perceptions from implementation of prevention policies.

En [country] el gobierno prohíbe - el uso de mascarillas en lugares públicos. (In (country), the government prohibited the use of masks in public places.) (Male participant, in his 50s, Central America)

The police harassed me when I was coming from the hospital at curfew hours. (Male participant, in his 40s, sub-Saharan Africa)

The cops scold us if they see us walking on the roads with face masks. (Male participant, in his 50s, South Asia)

I had to go to buy products, but police arrested my car, and sent me home. (Central Asian participant)

By the government, forbidding something as simple as going to the park while still allowing people to use public transport. (Male participant, in his 30s, Central Europe)

Bullied by politicians. Cat go to park with kids and play tennis. Only one person should go shopping. Being under house arrest wile criminals are set free. (Female participant, in her 50s, North America)
Mon cousin a été maltraité par la police parce qu'il s'est retrouvé dehors après le couvre-feu. (My cousin was mistreated by the police because he ended up outside after curfew.) (Female participant, late teens, sub-Saharan Africa)

One additional form of community-related COVID-19 harassment and bullying is through racist or other discriminatory actions, for instance:

Seen a lot of racist graffiti around my city towards Asians. Also heard [racist slur] a few times. (Male participant, in his 30s, from East Asia living in Northern America)

My nephew who is in fifth grade was bullied because of his nationality... (Female participant, in her 30s, from North America)

My grandparents are Asian and Chinese, all the news stories hurt them because so many racist things are happening to Asians right now... (Female participant, in her early 20s, from Northern America)

Soy asiática y al principio (Febrero y antes) la gente me trataba mal por la calle y me evitaba. (I am Asian and at the beginning (February and before) people treated me badly on the street and avoided me.) (Female participant, in her 30s, living in Southwestern Europe, from Southeastern Asia)

As I belong to a particular religion, the people near my home keep on bullying us for the coronavirus, which is not fair. (Moslem participant in South Asia, male, in his 20s)

Violence-both verbal and physical-was the third most commonly mentioned COVID-19-related bullying or harassment scenario, frequently linked to other coded thematic elements (such as the police, or racism).

I am of part Asian descent and have been bullied, harassed, spit on, blocked from getting goods, and told I am responsible for the 'Chinese Virus' even though I am not from China and my Parents and Grandparents and Great Grandparents were all from [Northern America]. (Male participant, in his 50s, Northern America)

The security agencies have been a pain, even hurting people for not beating the curfew... (Male participant, in his 40s, East Africa)

Chronically ill or folks with cancer being verbally abused by folks for wearing a mask (before the masks for everyone recommendation hit a few days ago)... (participant in their 30s, Northern America)

Told in shop to $\mathrm{f}^{* * *}$ off out of my space by someone. People are on short fuse and very nasty... (participant from Northern Europe)

People commonly report healthcare environments and personnel as important contextual elements of COVID19-related harassing and bullying situations, for example: 
Mi cuñada cometió el error de salir a la calle con ropa quirúrgica (no es ni médico ni enfermera pero trabaja en un hospital...) y la gente la agredió en la calle (sólo insultos, pero si tuvo miedo) (My sister-in-law made the mistake of going out in the street wearing surgical clothes (she is neither a doctor nor a nurse but works in a hospital...) and people attacked her on the street (only insults, but he was afraid). (Female participant, in her 30s, Central America)

Mi sobrina que es Médica, la hostigan en su domicilio los vecinos diciéndole que se vaya de alíi... (My niece, who is a doctor, is harassed at her home by the neighbors telling her to get out of there ...). (South American participant)

Mi hijo es médico y me lo han ofendido en la calle acusándolo de traer el virus (My son is a doctor and they have insulted me on the street accusing him of bringing the virus). (Male participant, in his 50s, Central America)

Mis familiares se dedican al sector salud, y sufrieron de hostigamiento por solicitar insumos de trabajo (My relatives are engaged in the health sector, and they suffered harassment for requesting labor supplies). (Male participant, in his 50s, Central America) Health care workers commonly note that their personal experiences of COVID-19-related harassment and bullying involve their professional identities and the visible manifestations of those identities to the public:

Yes I have had some verbally abuse me on social media including a friend who called me something very unpleasant because I was having a very emotionally difficult weekend. (Female participant, in her 50s, Northern Europe)

Unable to enter a supermarket because of being a nurse. (Male participant, in her 30s, Southeast Asia)

There have been isolated reports from some parts of the country that doctors have been harassed and asked to leave their apartment buildings. (Female participant, in her 30s, South Asia)

I've been ridiculed for trying to enforce physical distancing at my place of work. I've been purposely sneezed on at very close distance. There have been many rude and impatient customers that have been difficult to deal with. (Female participant, in her 50s, Northern America)

Salir con uniforme médico es complicado, la gente es muy ignorante y nos agrede (Going out with a medical uniform is complicated, people are very ignorant and attack us). (Female participant, in her 40s, Central America)

Pacientes exigen que se les atienda en servicios de emergencias en casos no urgentes (Patients demand that they be treated in emergency services in nonurgent cases). (South America participant)
Though less common, some participants report that medical personnel or institutions perpetrated COVID-19related harassing or bullying situations:

It was Doctors bullying the public when they should have had the courage to confront the Hospital CEO's and demand masks and PPE equipment be provided. I felt like saying 'you stay home so I can go out' besides if the infection control measures were correct then if I wore gloves and keep a TWO or THREE meter physical distance then no Doctor will come to harm. It was unfounded, hysterical, unethical cheap marketing ploy at best and an undeserved guilt trip on the public at worst. I think Doctors and Nurses asked over the top, unreasonable, and unjustifiable restrictions on the public, that is, to stay at home regardless of the cost. (Male participant, in his 60s, Oceania)

\section{DISCUSSION}

We have demonstrated that healthcare workers around the world are statistically significantly more likely to experience COVID-19-related harassment, bullying and hurt than others, even after controlling for a range of confounding factors. Historically, infectious diseases have faced the most powerful stigma among public health concerns. Furthermore, potentially deadly conditions, new diseases and illnesses without a known treatment or cure are other factors associated with an increased risk of experiencing stigmatisation. ${ }^{8}$

The lived experience of COVID-19-related bullying among our participants relates frequently to their public identities as healthcare workers visible in and traversing through the community, frequently intersecting with other domains such as police, racism and violence. There has been sharp increase in public sentiments of stereotyping and stigmatisation of racial minorities due to COVID-19, especially towards Asian people worldwide. ${ }^{29}{ }^{30}$ Racist and xenophobic rhetoric has spread along with the COVID-19 pandemic and is detrimental to the community's health, creating an atmosphere of fear and lack of safety. Perhaps as a consequence of this bullying and harassment, healthcare workers also are significantly more likely to feel that people with COVID-19 are gossiped about and lose status in the community. Interestingly, level of education-while higher in healthcare workers compared with others-was not associated with COVID-19-related bullying, suggesting that there was little difference in bullying experience among health workers in different roles. Similarly, while healthcare workers had significantly greater access to material assets (eg, car, home), these assets were not related to reduced experience of bullying.

Healthcare workers, perhaps unsurprisingly, are substantially immersed in direct COVID-19 experience: they are more likely to test positive for COVID-19 than others, more likely to feel they have had COVID-19 infection, and more likely to have known family, friends or 
neighbours that became sick with COVID-19 or to know people who have died from it. These experiences are strongly related to COVID-19-related harassment and bullying and may, in part, account for the higher prevalence of COVID-19-related stigma beliefs among healthcare workers.

As we observed, much of the exposure healthcare workers experience relates to their jobs; they are less likely to be able to do their jobs from home and are less likely to adhere to social-physical distancing, both of which place them at excess risk of experiencing COVID-19-related bullying by placing them in public and often in crowded situations. These situations are countered, perhaps, in that healthcare workers are significantly more likely to wear masks than others and wearing a mask is protective against COVID-19-related harassment and bullying. Healthcare workers commonly note that bullying they experience occurs in the context of public situations (eg, in stores, and in their housing situations) while en route to and from their jobs, and through encounters with police that exceed curfews because of work hours.

In an online study of 3551 non-health care workers in the USA and Canada, high percentage of Canadians and Americans believed that healthcare workers should not be allowed to go out in public, should have restrictions on their freedoms, should be isolated from community and should be separated from their families. ${ }^{10}$ Little has been done politically to recommend that healthcare workers be protected for carrying out their duties. ${ }^{10}$ The absence of protections-and indeed that bullying often arises from authorities-creates anxiety for health workers in that they subsequently confront bullying and stigmatising situations alone.

In part, stigma could be an expected consequence from the pandemic and from the resulting preventive strategies. Primary prevention of infection aims to reduce exposure to susceptible individuals as a source of infection. Due to their occupational exposure, healthcare workers are often viewed in the community as a potential source of the very infection that the community is trying to prevent. ${ }^{1013}$ The resulting stigma associated with COVID-19, however, threatens the physical and mental health of healthcare workers. ${ }^{9}$ A study including 906 healthcare workers from 5 major hospitals in Singapore and India reported a significant association between the prevalence of physical manifestation and psychological outcomes among healthcare workers during the COVID-19 outbreak. Results from the study identify headaches as the most common symptom and highlight a significant association between depression, anxiety, stress and PTSD with the presence of physical symptoms. ${ }^{31}$

We found that healthcare workers are significantly more likely to have child and elder care responsibilities, roles that are statistically significantly associated with greater COVID-19-related bullying. Healthcare workers are also more likely to be medically vulnerable themselves, being significantly more likely to have a chronic health condition and to live with someone in their household who has a chronic health condition. Social media usage is more common among healthcare workers and is generally protective against COVID-19-related bullying; that said, some participants report social media as the vehicle through which bullying occurs.

We found that about $13 \%$ of descriptions of harassing and bullying events were violent, either verbally or physically, the third most common code applied. Creating violence in workplaces leads to fear, worry and suffering of the healthcare workers' own mental and physical health. ${ }^{32}$ In the early phase of the pandemic, a qualitative study by Liu $e t$ al showed that the healthcare workers had strong sense of responsibility and teamwork while facing immense pressure of heavy workloads, lack of protective gear and feelings of powerlessness with patients. ${ }^{33}$ Over time, however, health worker's physical and psychological well-being is undermined by the constant pressures of discrimination, stigmatisation, social isolation and burnout which will be detrimental for controlling the spread of COVID-19. ${ }^{34}$

Prevalence of healthcare workers, COVID-19-related bullying and harassment and COVID-19-related stigma beliefs all varied significantly by region of the world. As a cluster, residents in Africa, Asia, Northern America and Oceania were more likely to experience bullying than their counterparts in Latin America and Europe. Residents of Asia, Africa and Latin America were also more likely to believe COVID-19 was a stigmatising condition, resulting in gossip and lower social status.

A study conducted among 3551 adult non-healthcare workers (1716 from the USA and 1835 from Canada) measured indicators of stigmatisation, COVID-19 stress syndrome and avoidance affecting healthcare workers. Their findings suggest that the tendency to stigmatise healthcare workers is associated with the COVID-19 stress syndrome that consists of fear that COVID-19 is highly dangerous, combined with the fear of being exposed to potentially contaminated surfaces or objects, fear about socioeconomic impact of COVID-19 and fear that foreigners are the source of infection. ${ }^{35}$ These factors appear related in our study as well, with a mix of harassing experiences relating to perceptions of both overcaution and undercaution, most commonly illustrated by masking in public places. Furthermore, incidents of racist harassment relate to perceptions of SARS-CoV-2's origins and fear of people perceived as 'foreign'. At least one previous study shows that the severity of the COVID-19 pandemic is associated with the tendency to overestimate health risks in general. ${ }^{10} 35$ COVID-related stigma around healthcare workers could be part of a wider tendency to overestimate health threats and to exaggerate perceptions. ${ }^{10}$

The global nature of COVID-19-related harassment and bullying study is further endorsed in numerous studies. Frontline health workers recovering from COVID-19 in Lagos State, Nigeria reported feeling stigmatised and psychologically and morally traumatised. When informed of their positive COVID-19 status the majority of the respondents (who were knowledgeable on COVID-19), 
however, reacted with denial, anxiety, distress, disorientation, crying for fear of stigmatisation. Some of the challenges postdiagnosis include loneliness, worries about the state of their families, non-disclosure of status to family members, isolation centres with limited space, insomnia and, paradoxically, stigmatisation by other health workers at the isolation centre. ${ }^{3}$ In Mexico, nurses were denied public transport and physically assaulted. ${ }^{13}$ In India, doctors were asked to vacate from their homes and attacked while carrying out their duties, believing them to be a source of infection that spread in housing complexes. ${ }^{36}$ Even children of doctors, ambulance drivers, family members of patients with COVID-19 and discharged patients were shunned by the community. In the Philippines, a nurse was attacked by men pouring bleach on his face. ${ }^{37}$ Many nurses are afraid to wear their uniforms outside of the healthcare settings, fearing for the safety of their own lives. ${ }^{38}$

Finally, media coverage could introduce fear and anxiety into people's psychological schemes of the 'unknown'. ${ }^{39}$ Selective reporting by the media about COVID-19 could drive fear and panic about being infected with the disease, leading to social stigma and discrimination of vulnerable populations. Healthcare workers are being shunned because people fear being infected by them. ${ }^{40}$ While media can have a positive effect by portraying healthcare workers as 'heroes', the negative psychological burden on the healthcare workers themselves can be enormous and exhausting. ${ }^{41}$ Distrust and panic towards healthcare workers potentially carrying COVID-19 further ostracise and oppress the very people who have the responsibility and training to care for sick patients with COVID-19. Interestingly, in our study, however, use of social media-which was significantly higher among healthcare workersappears protective against bullying; people who used social media daily in our study were more than one-third less likely to experience bullying. The potentially positive impact of social media use on COVID-19-related experience has been also found in other studies. ${ }^{42}$ This finding reinforces that most bullying and stigma experienced by healthcare workers occurs in the context of their daily lives in their communities, workplaces and travelling between the two.

\section{Strengths and limitations}

Our study is limited by our use of a single question to measure bullying and harassing experiences, where other studies of similar topics use more nuanced sets of measures. We also do not collect the participants' roles within the health settings where they work, which would perhaps distinguish the experiences of different job levels. Our use of social media also restricts the generalisation of our findings, in particular in that countries without access to Facebook and mTURK (eg, the People's Republic of China) are not represented. Also, as an anonymous survey with participants recruited through social media, we rely fully on self-reported data. People recruited through social media mechanisms may differ from others in the community with respect to literacy, technological access and resources. Furthermore, we have chosen to report UN regional and subregional aggregations of countries in our analyses rather than countries themselves to avoid stigmatisation based on our results. Our study, however, has several strengths, namely a large global sample size, four languages that cover much of the pandemic's reach at the time of data collection, a mixed-methods design and a robust guiding model of Critical Medical Ecology which helps contextualise concepts, roles and levels of impact.

\section{Recommendations}

In summary, healthcare workers are placed in closer contact with COVID-19 and the people infected by it. These workers are often vulnerable themselves (less job flexibility, more family responsibilities, greater medical risk) and even after controlling for a range of social and contextual variables, healthcare workers remain at considerable elevated risk of experiencing COVID-19related stigma and bullying. In addition to impacting their own lives, stigma and bullying against healthcare workers impacts—even destabilises—-their families, neighbourhoods and patients. Addressing this issue requires understanding and addressing why people harass and stigmatise healthcare workers, and should aim to destigmatise health workers through open dialogue and discussion among stakeholders in their communities. ${ }^{43}$ The United Nations has determined that violence against healthcare workers is a human rights violation and any acts of violence against healthcare workers discharging their duties should be condemned. ${ }^{5}$ In the midst of a pandemic, making work environments safe and implementing measures to protect healthcare workers, their patients and communities should be visioned as primary and essential prevention of COVID-19 itself, stress and mental health exacerbation at the individual and community levels and interpersonal violence.

Studies have shown that during public health emergencies, when immediate and reliable information is required, there are consistently, subgroups of people that are at greater risk of experiencing stigmatisation, discrimination and harassment; hence, will need special attention and protection. ${ }^{445}$ Efforts to reduce stigmatisation, bullying and harassment associated with COVID-19 cannot be isolated; actions should be the result of proactive collaboration between leaders from diverse sectors of our societies, including but not limited to governments, health organisations, religious leaders and public figures, such as athletes, communicators and social influencers.

Strategies for reducing healthcare worker risk of COVID-19-related bullying should include promotion of reliable and official sources of information, such as social media and other communication methods since misinformation can increase the levels of stress. Moreover, the message must be clear and oriented to increasing awareness while not promoting fear. Communities should be supported to identify and mitigate negative behaviours 
in order to support stigmatised groups. Lastly, groups at risk of experiencing stigmatisation and bullying, such as healthcare workers, should first count on support and effective measures of protection in and out of their workplaces and communities. ${ }^{43}$ Furthermore, healthcare workers at risk of or who have experienced any type of offence must be provided with psychological support to overcome the different forms of aggression.

Correction notice This article has been corrected since it first published. The provenance and peer review statement has been included.

Twitter Timothy D Dye @GlobalHealthNow

Acknowledgements The authors are grateful for the assistance of Connor DeAndrea-Lazarus, Kathleen Buckwell, Cody Gardner and Carrie Dykes for logistical assistance with developing, reviewing and implementing aspects of this project. The authors would also like to acknowledge the contributions of Wyatte Hall, Carrie Irvine, Dongmei Li, Erin Muir, José G. Pérez Ramos, Sophia Wiltse and Rebecca Royzer to the parent project of which this effort was a part.

Contributors TDD directed the design, implementation and analysis of this study, and led the development and revision of this manuscript. LA conducted background research and contributed to writing and revision of this manuscript. SSi contributed to this study's design, conducted background research and contributed to writing this manuscript. MB and SSh contributed to this study's design, reviewed and coded qualitative data and reviewed and edited drafts. TP reviewed and edited drafts and participated in the design of the study. EP contributed to the design of this study and reviewed the final manuscript. All coauthors reviewed and approved the final manuscript.

Funding This work was funded by The Richard W. \& Mae Stone Goode Foundation, Award \# 057843-002. Drs SSh and LA are trainees in the University of Rochester's Translational Biomedical Science PhD Program, which is supported by Grant 2TL1TR002000-05 from the National Center for Advancing Translational Sciences, National Institutes of Health. Dr LA is additionally supported by funds from BWF1014095 from the Burroughs Wellcome Fund. Drs SSi and TP are supported by the National Institute of General Medical Sciences of the National Institute of Health under Award Number K12GM106997. The authors also accessed the recruitment and REDCap resources of the University of Rochester CTSA, award number UL1 TR002001 from the National Center for Advancing Translational Sciences of the National Institutes of Health.

Conflict of interest statement The authors report no financial or other conflicts of interest with the content of this study. During the period of this study, Dr TDD was the Principal Investigator on unrelated grants and contracts from the US National Institutes of Health, Pfizer Global Medical Grants and the New York State AIDS Institute.

Map disclaimer The funders had no role in the study design, data collection and analysis, decision to publish or preparation of this manuscript.

Competing interests None declared.

Patient consent for publication Not required.

Ethics approval This study was performed in accordance with the ethical standards established by the 1964 Declaration of Helsinki and its later amendments. The University of Rochester's Research Subjects Review Board determined that this study met federal and University criteria for exemption (STUDY00004825).

Provenance and peer review Not commissioned; externally peer reviewed.

Data availability statement Data are available on reasonable request. Given the identifying and potentially stigmatising nature of the data in this study, analyses are provided in this paper to support its conclusions, although datasets are not publicly available. Interested investigators can request data from the corresponding author.

Supplemental material This content has been supplied by the author(s). It has not been vetted by BMJ Publishing Group Limited (BMJ) and may not have been peer-reviewed. Any opinions or recommendations discussed are solely those of the author(s) and are not endorsed by BMJ. BMJ disclaims all liability and responsibility arising from any reliance placed on the content. Where the content includes any translated material, BMJ does not warrant the accuracy and reliability of the translations (including but not limited to local regulations, clinical guidelines, terminology, drug names and drug dosages), and is not responsible for any error and/or omissions arising from translation and adaptation or otherwise.

Open access This is an open access article distributed in accordance with the Creative Commons Attribution Non Commercial (CC BY-NC 4.0) license, which permits others to distribute, remix, adapt, build upon this work non-commercially, and license their derivative works on different terms, provided the original work is properly cited, appropriate credit is given, any changes made indicated, and the use is non-commercial. See: http://creativecommons.org/licenses/by-nc/4.0/.

ORCID iD

Timothy D Dye http://orcid.org/0000-0002-9801-4712

\section{REFERENCES}

1 Link B, Hatzenbuehler ML. Stigma as an unrecognized determinant of population health: research and policy implications. $J$ Health Polit Policy Law 2016;41:653-73.

2 Link BG, Phelan JC. Conceptualizing stigma. Annu Rev Sociol 2001;27:363-85.

3 Kwaghe AV, llesanmi OS, Amede PO. Stigmatization, psychological and emotional trauma among frontline health care workers treated for COVID-19 in Lagos state, Nigeria: a qualitative study. 2020. https:// www.researchsquare.com/article/rs-53453/v1.

4 Sauer KS, Jungmann SM, Witthöft M. Emotional and Behavioral Consequences of the COVID-19 Pandemic: The Role of Health Anxiety, Intolerance of Uncertainty, and Distress (In)Tolerance. Int J Environ Res Public Health 2020;17:7241.

5 United Nations Security Council. Resolution 2286. 12 Dec 2016.

6 Safeguarding Health in Conflict Coalition. Health workers at risk: violence against health care, 2020. Available: www. safeguardinghealth.org

7 Devi S. COVID-19 exacerbates violence against health workers. Lancet 2020;396:658.

8 Brewis A, Wutich A, Mahdavi P. Stigma, pandemics, and human biology: looking back, looking forward. Am J Hum Biol 2020;32:e23480.

9 Bagcchi S. Stigma during the COVID-19 pandemic. Lancet Infect Dis 2020;20:782

10 Taylor S, Landry CA, Rachor GS, et al. Fear and avoidance of healthcare workers: an important, under-recognized form of stigmatization during the COVID-19 pandemic. J Anxiety Disord 2020;75:102289.

11 Ransing R, Ramalho R, de Filippis R, et al. Infectious disease outbreak related stigma and discrimination during the COVID-19 pandemic: drivers, facilitators, manifestations, and outcomes across the world. Brain Behav Immun 2020;89:555-8.

12 McKay D, Heisler M, Mishori R, et al. Attacks against health-care personnel must stop, especially as the world fights COVID-19. Lancet 2020;395:1743-5.

13 Diaz M. Coronavirus: health workers face violent attacks in Mexico. BBC news, 2020. Available: https://www.bbc.com/news/world-latinamerica-52676939

14 Dye T, Levandowski B, Li D, et al. Multilevel analysis of personal, non-medical COVID-19-Related impact worldwide. Ann Epidemiol 2020;52:116.

15 De Ver Dye T, Muir E, Farovitch L, et al. Critical medical ecology and SARS-COV-2 in the urban environment: a pragmatic, dynamic approach to explaining and planning for research and practice. Infect Dis Poverty 2020;9:1-7.

16 von Elm E, Altman DG, Egger M, et al. The strengthening the reporting of observational studies in epidemiology (STROBE) statement: guidelines for reporting observational studies. J Clin Epidemiol 2008;61:344-9.

17 Tong A, Sainsbury P, Craig J. Consolidated criteria for reporting qualitative research (COREQ): a 32-item checklist for interviews and focus groups. Int J Qual Health Care 2007;19:349-57.

18 Dong E, Du H, Gardner L. An interactive web-based dashboard to track COVID-19 in real time. Lancet Infect Dis 2020;20:533-4.

19 United Nations Statistics Division. Methodology-standard country or area codes for statistical use (M49) 2019 https://unstats.un.org/unsd/ methodology/m49/overview/

20 International Organization for Standardization. ISO country codes collection: online Browsling platform, 2020. Available: https://www. iso.org/obp/ui/

21 Difallah D, Filatova E, Ipeirotis P. Demographics and dynamics of mechanical Turk workers. Proceedings of the eleventh ACM International Conference on web search and data mining 2018:135-43. 
22 Shaver LG, Khawer A, Yi Y, et al. Using Facebook advertising to recruit representative samples: feasibility assessment of a crosssectional survey. J Med Internet Res 2019;21:e14021.

23 Sheehan KB, Pittman M. Amazon's mechanical turk for academics: the HIT handbook for social science research. Irvine, CA: Melvin \& Leigh, Publishers, 2016.

24 Moss AJ, Rosenzweig C, Robinson J. Is it ethical to use mechanical Turk for behavioral research? relevant data from a representative survey of MTurk participants and wages. 2020. https://psyarxiv.com/ $\mathrm{jbc} 9 \mathrm{~d} /$.

25 Dye T, Levandowski B, Siddiqi S. Non-medical COVID-19-related personal impact in medical ecological perspective: a global multileveled, mixed method study, 2020. Available: https://medrxiv. org

26 et alHamel L, Lopez L, Muñana C. KFF health tracking Poll March 2020, 2020. Available: https://www.kff.org/coronavirus-covid-19/pollfinding/kff-coronavirus-poll-march-2020/

27 Stangl A, Brady L, Fritz K. Technical brief: measuring HIV stigma and discrimination; international center for research on women, Washington D.C, USA; 20122018.

28 Hosmer Jr DW, Lemeshow S. Applied logistic regression. Hoboken: John Wiley \& Sons, 2004.

29 Roberto KJ, Johnson AF, Rauhaus BM. Stigmatization and prejudice during the COVID-19 pandemic. Administrative Theory \& Praxis 2020;42:364-78.

30 Kandil C. Asian Americans report over 650 racist acts over last week, new data says. NBC News 2020 https://www.nbcnews.com/news/ asian-america/asian-americans-report-nearly-500-racist-acts-overlast-week-n1169821

31 Chew NWS, Lee GKH, Tan BYQ, et al. A multinational, multicentre study on the psychological outcomes and associated physical symptoms amongst healthcare workers during COVID-19 outbreak. Brain Behav Immun 2020;88:559-65.

32 Sasaki N, Kuroda R, Tsuno K. Fear, worry and workplace harassment related to the COVID-19 epidemic among employees in Japan: prevalence and impact on mental and physical health, 2020. Available: https://papers.ssrn.com/sol3/papers.cfm?abstract_id= 3569887

33 Liu Q, Luo D, Haase JE, et al. The experiences of health-care providers during the COVID-19 crisis in China: a qualitative study. Lancet Glob Health 2020;8:e790-8.
34 Xiong Y, Peng L. Focusing on health-care providers' experiences in the COVID-19 crisis. Lancet Glob Health 2020;8:e740-1.

35 Taylor S, Landry CA, Paluszek MM, et al. Development and initial validation of the COVID stress scales. J Anxiety Disord 2020;72:102232.

36 Withnall A. Coronavirus: why India has had to pass new law against attacks on healthcare workers. The independent, 2020. Available: https://www.independent.co.uk/news/world/asia/coronavirusindia-doctor-nurse-attack-law-modi-health-care-workersa9480801.html

37 The Economist. Health workers become unexpected targets during COVID-19. The Economist, 2020. Available: https://www.economist. com/international/2020/05/11/health-workers-become-unexpectedtargets-during-covid-19

38 Semple K. 'Afraid to be a nurse': health workers under attack. The New York Times, 2020. Available: https://www.nytimes.com/2020/04/ 27/world/americas/coronavirus-health-workers-attacked.html

39 Chaiuk TA, Dunaievska OV. Fear culture in media: an examination on coronavirus discourse. Journal of History Culture and Art Research 2020;9:184-94.

40 Ramaci T, Barattucci M, Ledda C, et al. Social stigma during COVID-19 and its impact on HCWs outcomes. Sustainability 2020;12:3834.

41 Cox CL. 'Healthcare heroes': problems with media focus on heroism from healthcare workers during the COVID-19 pandemic. J Med Ethics 2020;46:510-3.

42 Al-Dmour H, Masa'deh Ra'ed, Salman A, et al. Influence of social media platforms on public health protection against the COVID-19 pandemic via the mediating effects of public health awareness and behavioral changes: integrated model. $J$ Med Internet Res 2020;22:e19996.

43 Baldassarre A, Giorgi G, Alessio F, et al. Stigma and discrimination (SAD) at the time of the SARS-CoV-2 pandemic. Int J Environ Res Public Health 2020;17:6341.

44 Abdelhafiz AS, Alorabi M. Social stigma: the hidden threat of COVID-19. Front Public Health 2020;8:429.

45 World Health Organization. Mental health and psychosocial considerations during the COVID-19 outbreak, 18 March 2020, 2020 Available: https://apps.who.int/iris/bitstream/handle/10665/331490/ WHO-2019-nCoV-MentalHealth-2020.1-eng.pdf 